Sains Malaysiana 47(1)(2018): 1-7

http://dx.doi.org/10.17576/jsm-2018-4701-01

\title{
Mating Calls of Selected Sarawak Toads (Amphibia: Anura: Bufonidae)
}

(Panggilan Pengawanan Kodok Sarawak Terpilih (Amfibia: Anura: Bufonidae)

\author{
MUHAMmad FADZIL AMrAm, RAMLAH ZAINUDiN* \& HASNIZAM ABDUl W AHID
}

\begin{abstract}
The sound produced by the anurans including toads can be a survival strategy for the selection of fittest males by their conspecific females and a form of effective prezygotic mechanism. Most of the published works on anuran sound production were on true frogs or ranids, yet little is known about sound characteristics of toads. Here we describe the properties of mating calls from six selected toad species from six study sites in Sarawak. Males' mating calls were recorded and analyzed using SoundRuler Acoustic Analysis ver 0.9.6.0. Call characteristic were subsequently compared for toad species differentiation. The results showed that each species differ in call characteristics, with pulsating note, rate of note repetition and pitch being the most apparent characters. The highest number of pulse notes belongs to Duttaphrynus melanostictus while Ansonia spinulifer exhibited highest pitch and rate of note repetition. These species'differences in mating call characteristics provide an additional method for anuran species classification besides morphological and molecular DNA data. It is also a very useful guide during field survey as the sound is audible and identification can be made without the need of capturing the toads.
\end{abstract}

Keywords: Bufonidae; call characteristics; note repetition rate; pitch; pulsating note

\section{ABSTRAK}

Bunyi yang dihasilkan oleh Anura termasuk kodok merupakan satu strategi kemandirian spesies dalam pemilihan baka jantan oleh betina serta sebagai suatu mekanisme pemencilan pra-zigot yang berkesan. Kebanyakan kajian bunyi anuran yang telah diterbitkan adalah daripada kodok (ranid), namun sedikit sahaja yang diketahui tentang ciri akustik kodok. Kajian ini mencirikan panggilan mengawan daripada enam spesies kodok terpilih dari enam tapak kajian di Sarawak. Bunyi panggilan kodok jantan direkod dan dianalisis dengan menggunakan Analisis Akustik SoundRuler ver 0.9.6.0. Ciri panggilan itu kemudiannya dibandingkan antara spesies kodok yang berbeza. Keputusan kajian menunjukkan bahawa panggilan jantan setiap spesies berbeza daripada segi denyutan bunyi, kadar pengulangan nota bunyian dan pic. Kekerapan tertinggi nota denyutan dimiliki oleh Duttaphrynus melanostictus manakala Ansonia spinulifer mempunyai pic dan kekerapan kadar pengulangan nota bunyian yang tertinggi. Penentuan ciri panggilan adalah sangat penting kerana ia menyediakan satu pendekatan tambahan untuk pengkelasan spesies anuran selain berdasarkan data morfologi dan molekul DNA. Ia juga amat berguna dalam kajian lapangan kerana bunyi boleh didengar dan dengan itu pengecaman spesies boleh dibuat tanpa penangkapan kodok.

Kata kunci: Bufonidae; ciri panggilan; kadar ulangan nota; nota denyut; pic

\section{INTRODUCTION}

The sound produces by animals such as the advertisement call of a toad contains key information about species identity and an individual's motivation to reproduce and can be used for species discrimination (Ryan 2009). Animal sounds are variables due to selective pressures that may influence the acoustic signals such as frequency bands and temporal components for effective communication (Radford et al. 2014). In anurans, sexual selection is a strong force of evolution. This occurs in the form of female choice on call frequency where spectral call characteristics such as dominant frequency are important to frog evolution (Ryan 1986). Female frogs or toads recognize male of their own species in mating through male mating calls which play an important role in prezygotic isolating mechanism (Dreher \& Prohl 2014). Failure to mate might result in offspring reduction that eventually leads to local extinction. According to Feng and Ratnam (2000), females are attracted to the calls with proper temporal structure. Temporal call structure includes call duration and number of pulses, where call duration can be a reliable indicator of heritable genetic quality (Welch et al. 1998). Another important temporal characteristic is pulse rise time (Gerhardt \& Huber 2002).

Since Sarawak consists of at least 150 species of frogs and toads (Inger \& Stuebing 2005). However, little is known of the Sarawak Anuran's sounds to date except in Zainudin et al. (2012, 2010). Therefore, our main objective was to describe the acoustic sounds produced by selected species of male toads in Sarawak. 


\section{MATERIALS AND METHODS}

Mating calls of six species of Sarawak toads were recorded from six localities throughout Sarawak (Figure 1) namely Anna Rais, Padawan ( $\mathrm{N} 01^{\circ} 07.922^{\prime} \mathrm{E}$ $\left.110^{\circ} 16.108^{\prime}\right)$, Gading National Park (N 0141.495' E $\left.109^{\circ} 50.927^{\prime}\right)$, Kubah National Park (N 0136'19.3” E $110^{\circ} 11^{\prime} 30.3$ '), Matang Wildlife Center (N 01'36'40.4" E 11009'49.7”), Mulu National Park (N 0403.021' E $\left.114^{\circ} 51.399^{\prime}\right)$, Batang Ai National Park (N 01 ${ }^{\circ} 18.148^{\prime}$ E $\left.112^{\circ} 04.581^{\prime}\right)$ and Bako National Park (N 01 ${ }^{\circ} 42.943^{\prime}$ E $\left.110^{\circ} 26.752^{\prime}\right)$. The GPS coordinates were taken using GPSmap 60CSx (GARMIN).

At least 2-3 individual males of each Sarawak Bufonids were recorded using an Olympus Linear PCM recorder model LS-11 and a unidirectional microphone. Most of the mating calls recorded were in .wav format or converted to .wav using XviD4PSP 5 EVR SoundConverter. Calls were analyzed for $60 \mathrm{~s}$, from two to three individuals (Leong et al.2003) or depending on the number of males caught, using SoundRuler Acoustic Analysis ver 0.9.6.0 (Gridi-Papp 2003-2007). The terminologies for acoustic characteristics are following Littlejohn (2001), Matsui (1997) and SoundRuler variables (Bee 2003) (Table 1).

\section{RESULTS AND DISCUSSION}

All the six different species of toads investigated showed different mating call characteristics, but only note repetition rate appeared significantly differed among species (Table 2). Call characteristics of selected species of the Family Bufonidae were described as below:

\section{ANSONIA SPINULIFER}

The male of A. spinulifer (Spiny Slender Toad) can be found at night, sitting and calling on low vegetation. The calls produced are continuous repetitive high pitching note (Figure 2(a)) with each note consisting of two pulses (Figure 2(b)). This species has a very high note repetitive rate, presumably to attract the opposite sex more effectively while sitting on low vegetation (Inger \& Stuebing 2005). The spectrogram showed that this species emits high pitch call ranging from 4 to 5 kiloHertz $(\mathrm{kHz})$ (Figure 2(c)). Only one peak of highest amplitude spectrum observed in Figure 2(d).

\section{INGEROPHRYNUS DIVERGENS}

The oscillogram of the call of Ingerophrynus divergens was shown in Figure 3.I. divergens has a querulous, raspy



FIGURE 1. Map of Sarawak, Malaysian Borneo and Peninsular Malaysia

TABLE 1. List of call variables measured in this study

\begin{tabular}{lll}
\hline & Variable/characters & Measured characteristics \\
\hline 1 & Note & Pulse group \\
2 & Note duration & $\begin{array}{l}\text { Time from the beginning of the first pulse to the end of the last pulse in a note. } \\
\text { Measured from waveform analyzer screen. }\end{array}$ \\
3 & Note gap & Time from the beginning of one note to the beginning of the next note \\
4 & Note repetition Rate & Number of notes per second
\end{tabular}

Bee 2003; Matsui 1997; Zainudin et al. 2010 
TABLE 2. Summary of call characteristics of selected Sarawak Bufonidae

\begin{tabular}{lcccc}
\hline & \multicolumn{4}{c}{ Call characteristics } \\
\cline { 2 - 5 } Species & $\begin{array}{c}\text { No. of pulsed } \\
\text { notes }\end{array}$ & $\begin{array}{c}\text { Note repetition /60 } \\
\text { sec }\end{array}$ & Pitch (kHz) & $\begin{array}{c}\text { Number of } \\
\text { amplitude spectrum }\end{array}$ \\
\hline Ansonia spinulifer & 2 & 225 & High (4.5-5) & 1 \\
Ingerophrynus divergens & 5 & 45 & Moderate (1-3) & 2 \\
Phrynoidis asper & 2 & 4 & Very low (1) & 1 \\
Phrynoidis juxtasper & 2 & 29 & Very low (1-2) & 1 \\
Pedostibes hosii & 3 & 2 & Very low (1) & 1 \\
Duttaphrynus melanostictus & 6 & 184 & Moderate (1-3) & 2 \\
Nonparametric Runs Test & $0.72^{\mathrm{NS}}$ & $0.48^{*}$ & & $0.72^{\mathrm{NS}}$ \\
\hline
\end{tabular}

*exact significant at $p=0.5$; ${ }^{\mathrm{NS}}$ Not significant
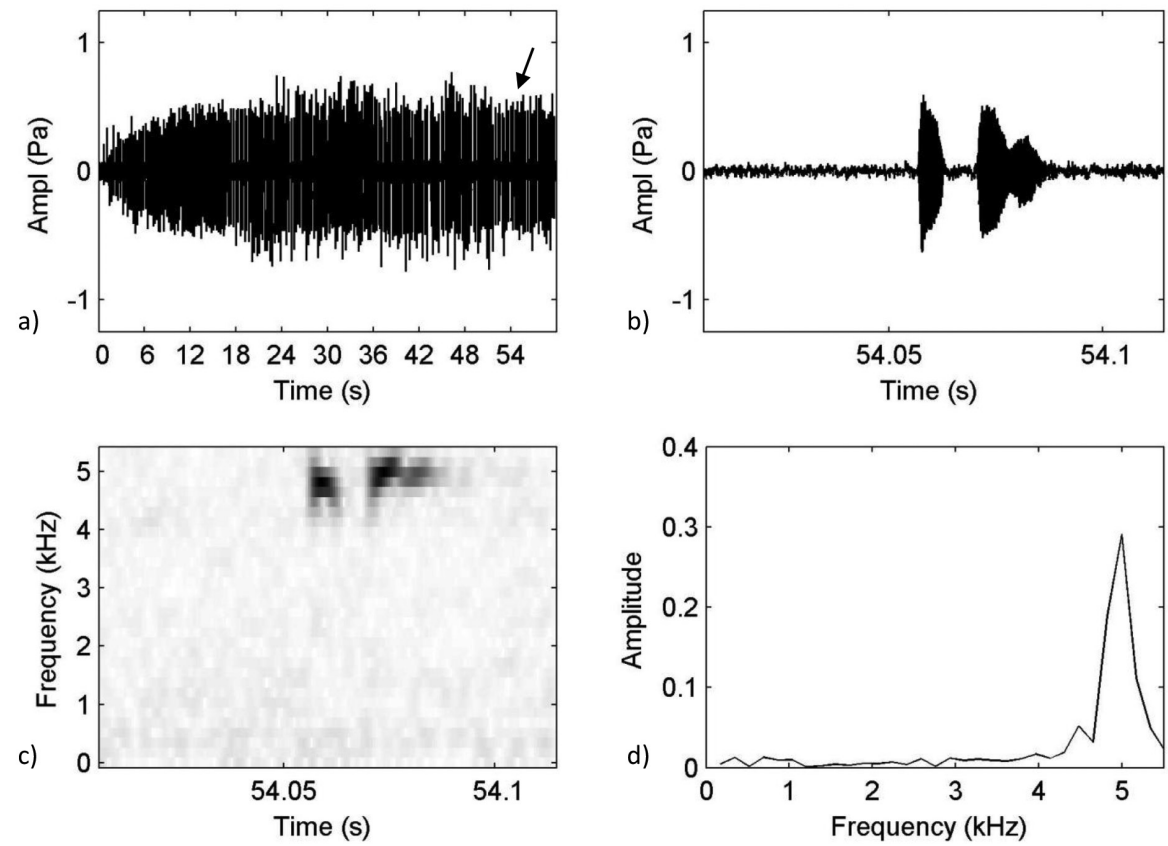

FIGURE 2. The oscillogram of the call of Ansonia spinulifer showing a) oscillogram of the call (60 s), b) oscillogram of one note, c) spectrogram of one note and d) amplitude spectrum of one note

with rising thrill calls (Inger \& Stuebing 2005). The calls produced continuous repetitive medium pitch note (Figure 3(a)). Each note consists of five pulses (Figure 3(b)). This species lives on the forest floor, where vocalization can be heard in chorus near the intermittent pool of stagnant or slow-flowing water. The spectrogram showed that this species emits medium pitched call ranged from 1 to $3 \mathrm{kHz}$ (Figure 3(c)). There are two peaks of the highest amplitude spectrum observed in Figure 3(d).

\section{PHRYNOIDIS ASPERA}

Phrynoidis aspera is a large river toad that can be found at large river banks, producing hoarse low-frequency calls with two pulsed notes (Figure 4(b)) and four repetitive notes per $60 \mathrm{~s}$ for this study (Figure 4(a)). This species has loud calls, low pitch with a frequency of $1 \mathrm{kHz}$ and low note repetition rate. The amplitude spectrum appeared as only one high peak as shown in Figure 4(d).

\section{PHRYNOIDIS JUXTASPERA}

Phrynoidis juxtaspera is a closely related species of $P$. aspera and produced calls which are hoarse, squeaky croak or chirp (Inger \& Stuebing 2005). However, unlike P. aspera, P. juxtaspera produced continuous repetitive low pitch note, with increasing intensity (Figure 5(a)). Each note consists of two pulses (Figure 5(b)). The spectrogram showed that this species emits low-pitched call ranged from 1 to $2 \mathrm{kHz}$ (Figure 5c). Only one peak of highest amplitude spectrum is observed in Figure $5 \mathrm{~d}$.

\section{PEDOSTIBES HOSII}

The advertisement calls of Pedostibes hosii consists of three pulsed notes (Figure 6(b)), with two repetitive notes per $60 \mathrm{~s}$ for this study (Figure 6(a)). The spectrogram showed this species emits low pitch calls with a frequency of $1 \mathrm{kHz}$ (Figure 6(c)). P. hosii is a tree toad and vocalization can only be heard when the adult toad come down to the river 

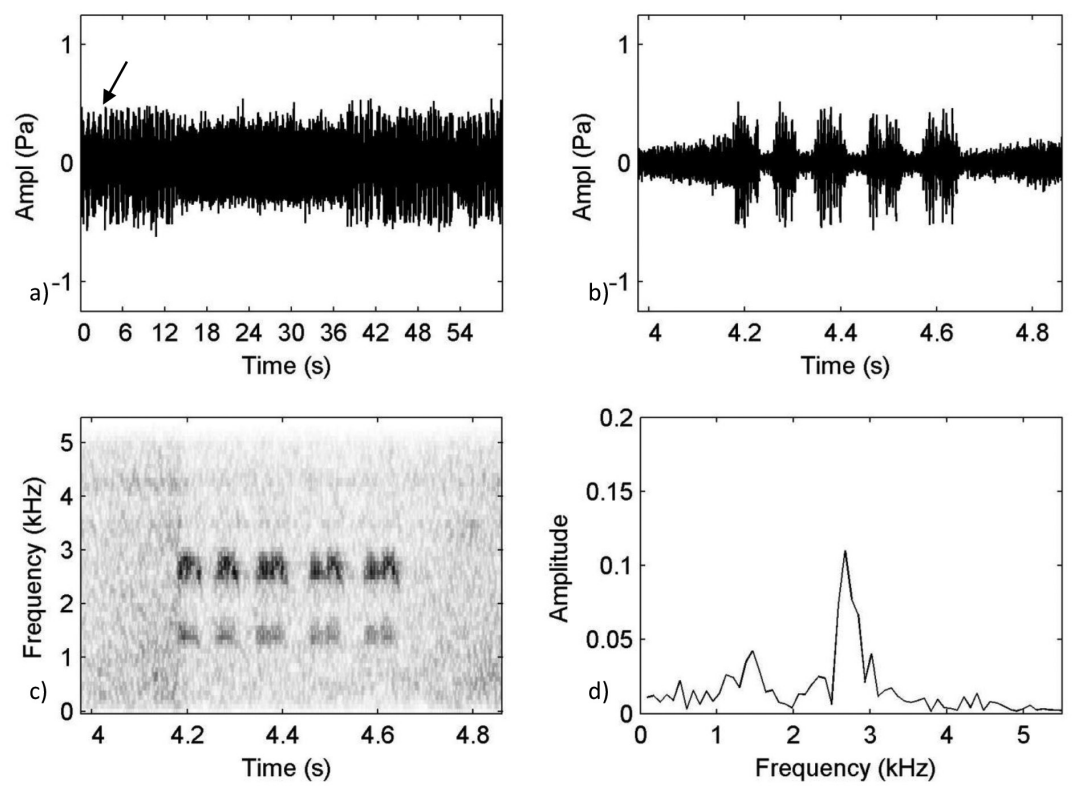

FIGURE 3. The oscillogram of the call of Ingerophrynus divergens showing a) oscillogram of the call (60 s),

b) oscillogram of one note, c) spectrogram of one note and d) amplitude spectrum of one note
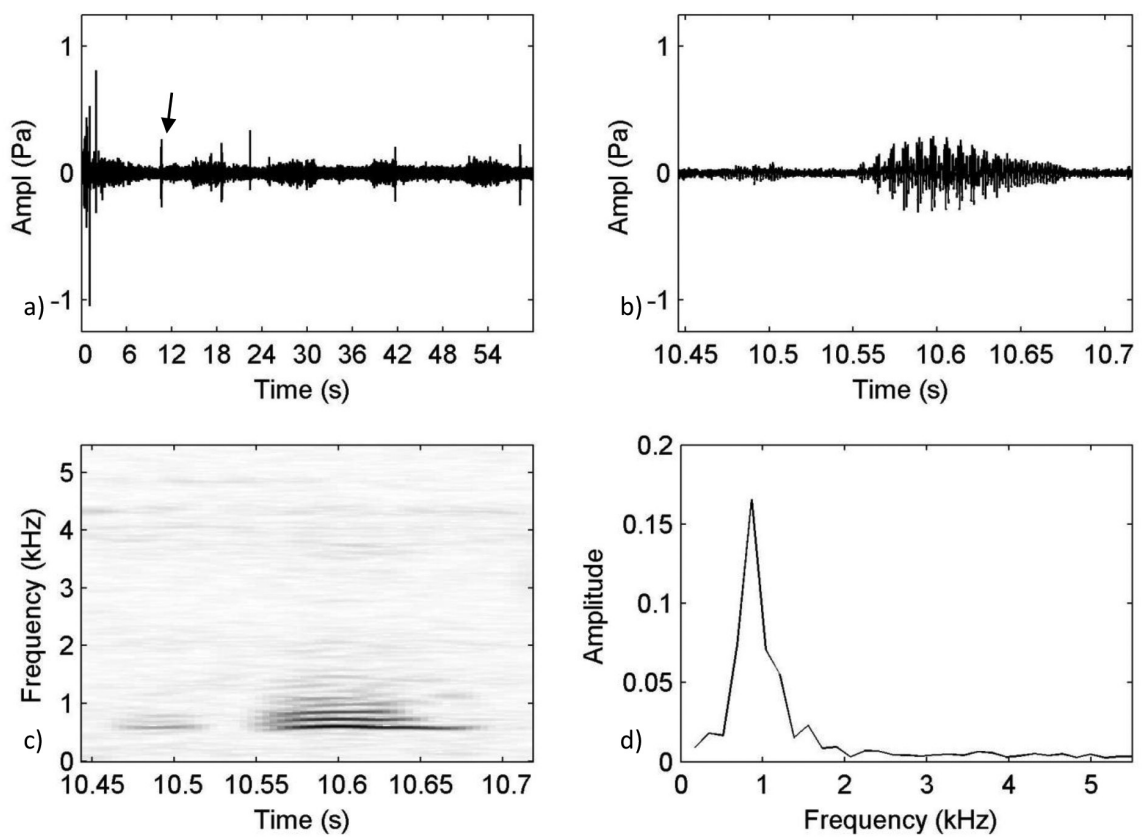

FIGURE 4. The oscillogram of the call of Phryonoidis asper showing a) oscillogram of the call (60 s),

b) oscillogram of one note, c) spectrogram of one note and d) amplitude spectrum of one note

to breed. During mating season, a male toad can be found sitting on a low tree branch or overhanging tree roots (Inger \& Stuebing 2005). The amplitude spectrum appeared only one highest peak as shown in Figure 6(d).

\section{DUTTAPHRYNUS MELANOSTICTUS}

Duttaphrynus melanostictus (Common Sunda Toad) produced continuous repetitive low-medium pitch note (Figure 7(a)). Each note consists of 6 pulses (Figure 7(b)).
Different from other Bornean toads, D. melanostictus does not live in the forest but prefers habitat near human settlements. This might explain why it has high note repetition rate, as to counter the acoustic interference from noisy human settlements (Luther 2008). The spectrogram showed that this species emits low to medium pitched call ranged from 1 to $3.5 \mathrm{kHz}$ (Figure 7(c)). The frequency range is somewhat similar to that of Duttaphrynus scaber from Western Ghat (Padhye et al. 2013). D. scaber which 

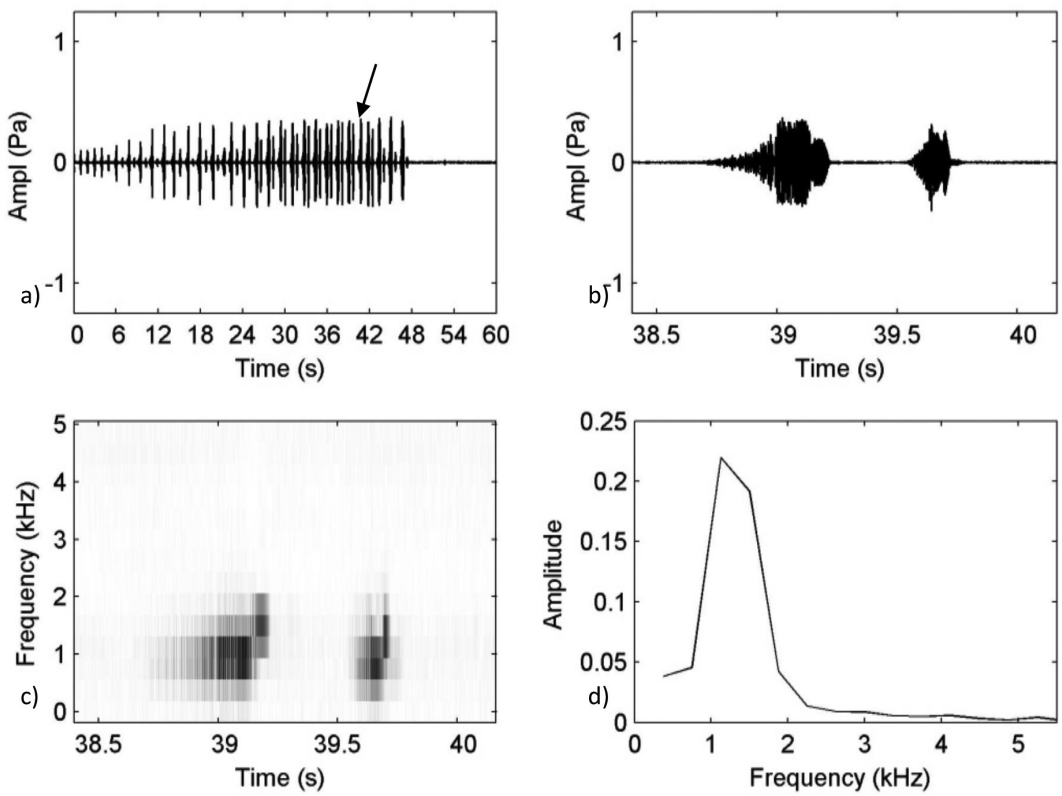

FIGURE 5. The oscillogram of the call of Phryonoidis juxtasper showing a) oscillogram of the call (60 s),

b) oscillogram of one note, c) spectrogram of one note and d) amplitude spectrum of one note
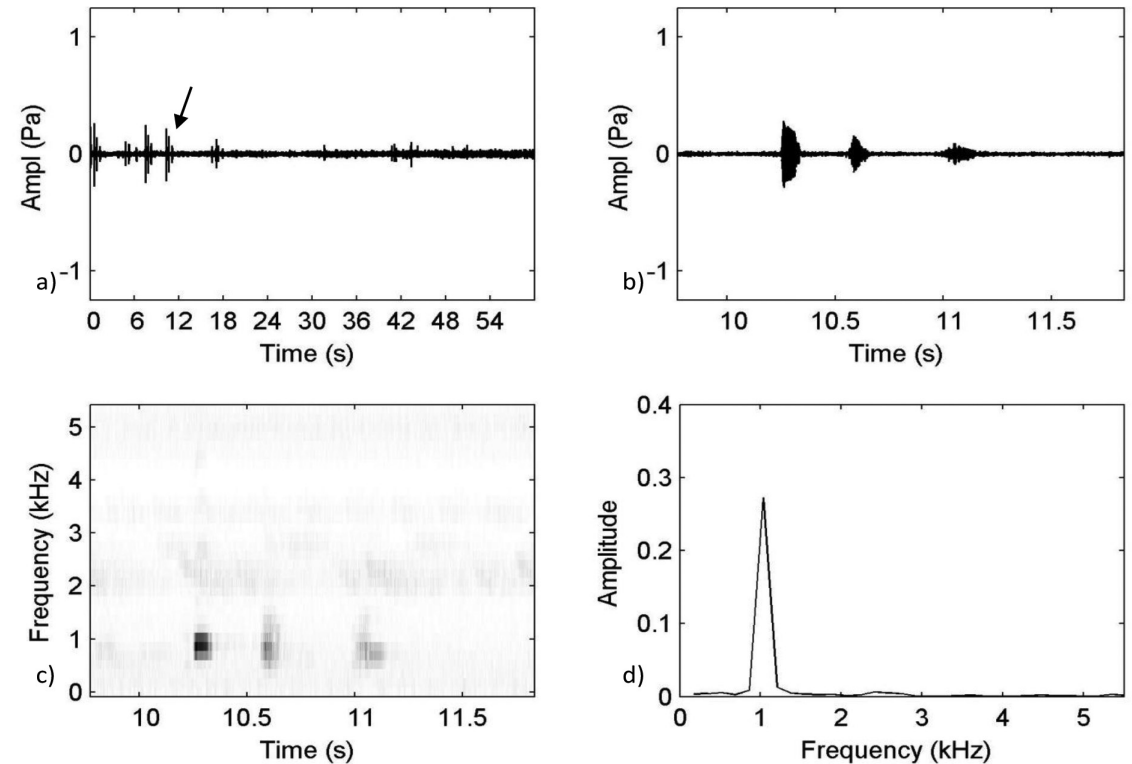

FIGURE 6. The oscillogram of the call of Pedostibes hosii showing a) oscillogram of the call ( $60 \mathrm{~s})$,

b) oscillogram of one note, c) spectrogram of one note and d) amplitude spectrum of one note

is smaller in size has a higher frequency range, from 2.5 to $4.5 \mathrm{kHz}$; with similar call pattern as D. melanostictus. There are two peaks of the highest amplitude spectrum observed in Figure 7(d).

The mating calls of $P$. hosii, $P$. aspera and $P$. juxtaspera, which are the larger toads among the species studied, fitted the description by Alonso and Rodriquez (2003) that 'the larger the body size of a frog, the lower frequency of the sound it will produce'. These species produced mating calls with low frequency around 1 $\mathrm{kHz}$ compared to the high frequency mating calls by the smallest frog, A. spinulifer, which is at 4.5 to $5 \mathrm{kHz}$. In addition, the largest toad, $P$. juxtaspera produce loud and long-mating calls with trains of complex pulses similar to that of large Bufo species (Alonso 2003). Phrynoidis justaxpera is a larger size of toad than P. aspera, however $P$.justaxpera has a higher note repetition rate and a slightly higher dominant frequency. The call frequency ranged from 1 to $2 \mathrm{kHz}$, which is slightly higher than P. aspera $(1 \mathrm{kHz})$. $D$. melanostictus and I. divergens which are the mediumsize toads, produce mating calls with a higher dominant frequency compared to the larger toad. Study by Alonso 

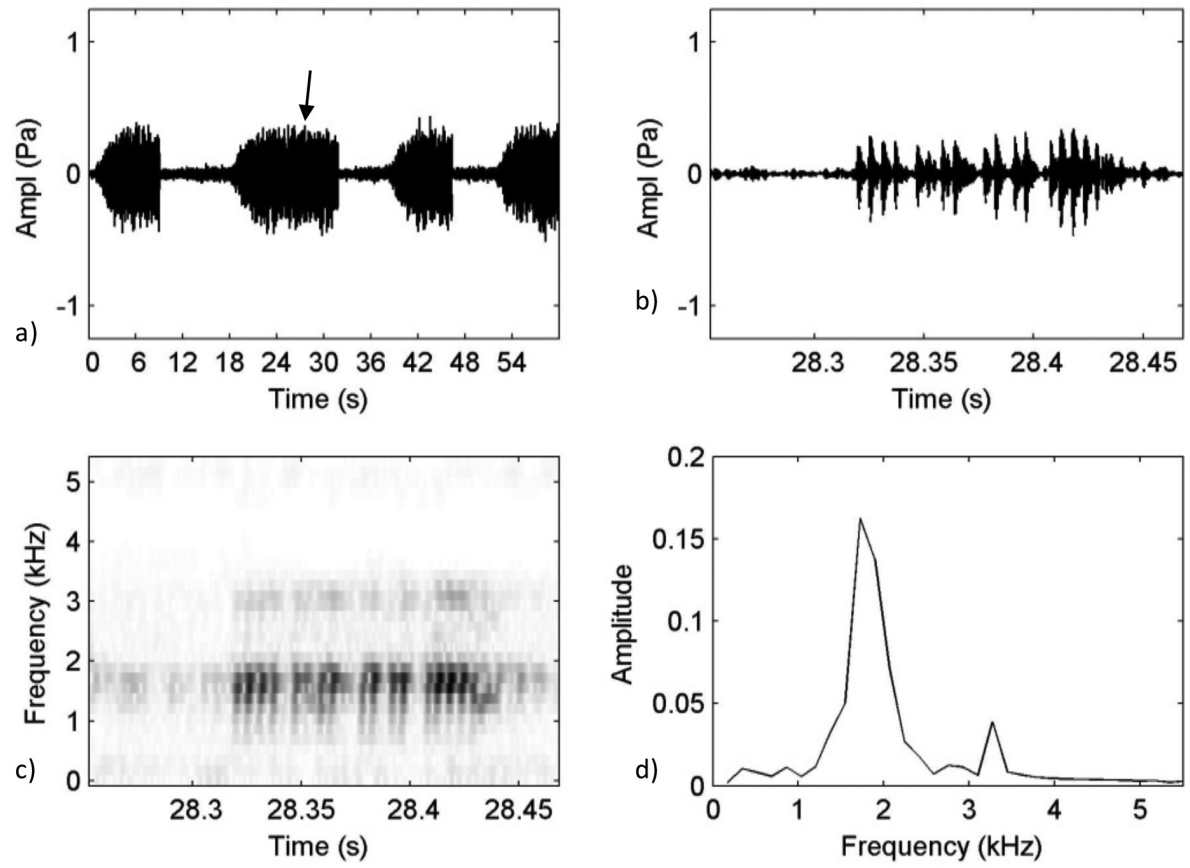

FIGURE 7. The oscillogram of the call of Duttaphrynus melanostictus showing a) oscillogram of the call $(60 \mathrm{~s}), \mathrm{b})$ oscillogram of one note, c) spectrogram of one note and d) amplitude spectrum of one note

and Rodriquez (2003) shows that the call of smaller Bufo species consist of short trains of single pulses of similar duration, which is different from the results obtained, as in A. spinulifer, with two pulses call of different duration (Figure 2(b)) and I. divergens, with five pulses call (Figure 3(b)).

Duttaphrynus melanostictus demonstrated the highest numbers of pulsating notes in mating calls while Ansonia spinulifer had the highest note repetition rate and pitch. However, the amplitude spectrums are very similar between species, where most species have one-amplitude spectrum, except for Ingerophrynus divergens and $D$. melanostictus with two-amplitude spectrum. The results were consistent with other studies that presented significant difference of note repetition rate among species (Leong et al. 2003; Zainudin et al. 2010), thus suggesting that the character (note repetition rate) is a reliable indicator for discrimination of frog species. In contrast, the finding was not consistent with Sarawak true frog (Genus Hylarana) where the number of pulsed note was able to discriminate the Hylarana group (Zainudin et al. 2010) but not the bufonids in this study. Only note repetition rate can be used to discriminate species of the Sarawak bufonids. Number of pulse note, pitch and amplitude spectrum were unable to discriminate the species, thus implying that the usage of call characters for discriminating frogs and toads are depending on the taxonomic grouping of each species. Hence more call characters should be included in the analysis for further research, such as call duration and number of pulses (Feng \& Ratnam 2000), call duration (Welch et al. 1998) and pulse rise time (Gerhardt \& Huber 2002).
The results of this study were consistent with the study by Zainudin et al. (2010) which showed that advertisement call characteristics are good characters for species recognition. Because mating calls of a species are always highly characterized, they are useful to evaluate inter and intraspecific relationships, and often better than morphological characteristic (Kanamadi et al. 1993; Schneider et al. 1986).

\section{CONCLUSION}

Based on the result, mating calls of selected Sarawak toad were successfully described. Note repetition rate is a good indicator for discrimination of Sarawak toad species. The identification of calling characters can be used as an additional method to compliment morphological examination and molecular techniques for species identification. Compared to morphology and phylogeny, this method is harmless for toad since it can be done by recording and analysing the calls without capturing them.

\section{ACKNOWLEDGEMENTS}

This study was funded by UNIMAS research grant FRST/01(21)/753/2010(39) and FRGS/1/2013/STWN10/ UNIMAS/02/3.

\section{REFERENCES}

Alonso, R. \& Rodriguez, A. 2003. Advertisement calls of Cuban toads of the genus Bufo (Anura, Bufonidae). Phyllomedusa 2(2): $75-82$ 
Bee, M.A. 2003. Sound ruler: A free, open code, multi-platform sound analysis and graphing package. Bioacoustics 14: 171-178.

Dreher, C.E. \& Prohl, H. 2014. Multiple sexual signals: Calls over color for mate attraction in an aposematic, color-diverse poison frog. Frontiers in Ecology and Evolution 2(22): 01-10.

Feng, A.S. \& Ratnam, R. 2000. Neural basis of hearing in realworld situations. Annu. Rev. Psychol. 51: 699-725.

Gerhardt, H.C. \& Huber, F. 2002. Acoustic Communication in Insect and Frogs: Common Problems and Diverse Solutions. Chicago: University of Chicago Press.

Gridi-Papp, M. 2003-2007. SoundRuler: Acoustic Analysis for Research and Teaching. http://soundruler.sourceforge.net. Accessed on 10 December 2013.

Inger, R.F. \& Stuebing, R.B. 2005. A Field Guide to the Frog of Borneo. 2nd ed. Kota Kinabalu: Natural History Publications (Borneo).

Kanamadi, R.D., Schneider, H., Hiremath, C.R. \& Jirankali, C.S. 1993. Vocalization of the tree frog Polypedates maculatus (Rhacophoridae) J. Biosci. 18(2): 239-245.

Leong, T.M., Matsui, M., Yong, H.S. \& Abdul Hamid, A. 2003. Revalidation of Rana laterimaculata Barbour et Noble, 1916 from the synonym of Rana baramica Boettger, 1901. Curr. Herpetol. 22(1): 17-27.

Littlejohn, M.J. 2001. Pattern of differentiation in temporal properties of acoustic signals of anurans. In Anuran Communication, edited by Ryan, M.J. Washington: Smithsonian Institution Press. pp. 102-120.

Luther, D.A. 2008. The evolution of communication in a complex acoustic environment. $\mathrm{PhD}$ dissertation. University of North Carolina, Chapel Hill, United States of America. (unpublished).

Matsui, M. 1997. Call characteristics of Malaysian Leptolalax with a description of two new species (Anura: Pelobatidae). Copeia 1997(1): 158-165.

Padhye, A., Pandit, R., Patil, R., Gaikwad, S., Dahanukar, N. \& Shouche, Y. 2013. Range extension of Ferguson's toad Duttaphrynus scaber (Schneider) (Amphibia: Anura: Bufonidae) up to the northern most limit of Western Ghats, with its advertisement call analysis. Journal of Threatened Taxa. 5(11): 4579-4585.

Radford, A.N., Kerridge, E. \& Simpson, S.D. 2014. Acoustic communication in a noisy world: Can fish compete with anthropogenic noise? Behav. Ecol. 25(5): 1022-1030.

Ryan, M.J. 1986. Factors influencing the evolution of acoustic communication: Biological constraints. Brain Behav. Evol. 28: $70-82$.
Ryan, M.J.2009.Communication in frogs and toads. Encyclopedia of Neuroscience 2: 1159-1166.

Schneider, H., Hussein, F. \& Akef, M.S.A. 1986. Comparative bioacoustic studies in the yellow-bellied toad, Bombina variegata $(\mathrm{L})$, and relationship of European and Asian species and subspecies of the genus Bombina (Anura, Amphibia); Bonn. Zool. Beitr. 37: 49-67.

Welch, A.M., Semlitsch, R.D. \& Gerhardt, H.C. 1998. Call duration as an indicator of genetic quality in male gray tree frogs. Science 280(5371): 1928-1930.

Zainudin, R., Wahid, H.A. \& Rahman, M.A. 2012. Croaks of the Bornean Frog: The Hylarana of Sarawak. UNIMAS Publication, ISBN 978-967-5527-13-5.

Zainudin, R., Rahman, M.A., Mohd Zain, B.M., Nor, S.M., Norhayati, A. \& Inger, R.F. 2010. Advertisement call description of five species of Bornean frogs from the genus Hylarana Tschudi 1838 (Amphibia, Anura, Ranidae) from Sarawak, Malaysia (Borneo). Sains Malaysiana 39(3): 363-369.

Muhammad Fadzil Amram

Department of Zoology

Faculty of Resource Science and Technology

Universiti Malaysia Sarawak

94300 Kota Samarahan, Sarawak Bumi Kenyalang

Malaysia

Ramlah Zainudin*

Pusat Pengajian Pra-Universiti

Universiti Malaysia Sarawak

94300, Kota Samarahan, Sarawak Bumi Kenyalang

Malaysia

Hasnizam Abdul Wahid

Faculty of Applied and Creative Arts

Universiti Malaysia Sarawak

94300 Kota Samarahan, Sarawak Bumi Kenyalang

Malaysia

*Corresponding author; email: zramlah@.unimas.my

Received: 27 February 2015

Accepted: 15 June 2017 